\title{
Potential Directions of Strategic Development of Medical Tourism: The Case of the Republic of Croatia
}

\author{
Tatjana Gredičak ${ }^{A^{*}}$, Damir Demonja ${ }^{B}$ \\ Received: April 27, 2019 | Revised: September 04, 2019 | Accepted: October 17, 2019 \\ doi: $10.5937 / g p 24-21485$
}

\begin{abstract}
Strategic product development in the offer of specific forms of tourism takes place very dynamically and is an example of using the diversification strategy as the dominant development strategy. Once relatively inelastic market offers, it becomes more elastic and with the market demand realizes new forms of partnership based on meeting the demand of each tourists individually. A large number of tourist offer products are adjusted to a smaller segment of consumers, i.e. tourists. The life span of tourism products and services is relatively short. The research for this paper is of a scientific character; it is motivated by the applicative need and in that sense it is applicable. Within the framework of economic science, the basic goal of the paper is to establish and analyze elements in the market that determine the development of medical tourism. The aim is to explore the place and role of strategic management in the function of products and services distribution for medical tourism. The paper attempts to explore the relevance of the valorization potential of medical tourism in the continuous efforts to improve tourism in the Republic of Croatia. This is shown by an analysis of the implementation of the priority tourism policy measures defined by the Strategy for development of tourism of the Republic of Croatia to 2020, i.e. the implementation of the Action Plan for development of health tourism of the Republic of Croatia in relation to the anticipated dynamics of the implementation of the proposed programs. Regarding the programs, in order to increase the competitiveness of medical tourism, the paper discusses the improvement of quality offers in the field of medical tourism through the implementation of quality, accreditation and certification of health facilities. Also, activities carried out at the current moment in the field of medical tourism in the Republic of Croatia are also shown.
\end{abstract}

Keywords: Republic of Croatia; medical tourism; strategy; management; development; quality

JEL Classification: A11, M38, Z32

\section{Introduction}

Mass tourism has affected the development of many underdeveloped regions, but has also caused a series of negative effects. They are visible in the disruption of natural beauty, environmental pollution and in other environmental, social, cultural and economic chang- es. As a counterbalance to mass tourism first appeared the term "alternative", this was later changed to the term sustainable. The term "selective tourism" appears in the scientific literature in early 1970s. That term was preceded by a similar term, and the primary

\footnotetext{
A Ministry of Tourism Republic of Croatia, Zagreb, Croatia; e-mail: tatjana.gredicak@kr.t-com.hr

B Senior scientific adviser in permanent position, Institute for Development and International Relations, IRMO, Zagreb, Croatia

* Corresponding author: Damir Demonja; email: ddemonja@irmo.hr
} 
goal was the classification of tourist types as opposed to mass tourism. In theory and practice for specific forms of tourism, the following terms are used: individual, responsible, specific, tourism based on special interests, selective, thematic and alternative (Geić, 2011: 475).

The definition of specific forms of tourism at Alfier is: "Selective types of tourism are those that, with their content, with regard to the place where they occur and the time they are taking place, can best satisfy the dominant motives in the sphere of tourist demand: the desire for a return to original nature, innate the need of all people for play and playing and the need to communicate with other people, as well as all other vital, bioantropological and psychosocial needs that an increasing number of people, living in an environmentally degraded and fully aligned urban environment, cannot satisfy in everyday life" (Alfier, 1994: 171). An important feature of specific forms of tourism is the diversification of offer and tourism products. At the center of interest are the motives that move people on tourist trips, so the development concept of tourism in tourist destinations is aimed at meeting the specific needs of a narrower segment of consumers in a market that is homogeneous in view of their particular interest. Thus, since the 1990s, the term "specific forms of tourism" has become increasingly frequent in theory and practice, which is a free translation from the Englishspeaking word "special interest tourism". Some Croatian authors use "selective forms of tourism" for this term, which is semantically completely unacceptable, as is the term "alternative tourism", which is abandoned in recent world literature (Čavlek et al., 2011: 39-40).

Health, spa and medical tourism is most often perceived as synonyms, but among them there are differences which will be discussed further below. Medical tourism, which takes place in medical consulting rooms, clinics/health centers and special hospitals, involves traveling to other destinations in order to achieve health care which includes, for example, partial surgical procedures, as well as dental, cosmetic, psychiatric and alternative treatments/procedures along with the corresponding care and recovery services. Spa tourism, which takes place in health resorts (spas) and specialized hospitals, involves professional and controlled use of natural healing factors and physical therapy procedures to preserve and improve health and quality of life. The emphasis is on the revitalization of psychophysical capabilities in climate, sea and in thermal destinations/health resorts through treatments, special programs of recovery, a balanced diet and the like. Wellness tourism, which takes place mainly in hotels and health resorts (spas), means achieving physical and spiritual equilibrium, where it is necessary to differentiate between medical and holistic health. Medical wellness has been organized to provide health-preventive and curative programs for the prevention of illness and the preservation and improvement of health with a multidisciplinary team that necessarily includes a physician as well as other professional staff (e.g. physiotherapist, kinesiologist, nutritionist). Methods and procedures of medical wellness include methods of conventional, complementary and traditional medicine. Holistic wellness includes other, very diverse non-medical wellness offer (National program - Action Plan for development of health tourism of the Republic of Croatia, 2014: 8).

With regard to complementarity, health and medical tourism is often studied in literature in parallel. For most authors, medical tourism is a segment of health tourism, but because of the great connection and similarity of medical and health tourism, they are most frequently used alternately, so there is contradiction in defining and publishing the realized effects. This contributes to the impossibility of keeping accurate records of tourist activities in health tourism. The literature states that health tourism involves organized travel outside their local community with the aim of maintaining, improving and restoring physical and mental condition of man. Health tourism through a holistic approach includes health care, beauty treatments, nutrition/diet, detoxification, thalassotherapy and kinetic therapy, i.e. different wellness/spa treatments, and is based on accommodation capacities, natural health resorts/spas, medical supervision and conditions for the implementation of health programs accompanied by a number of ancillary services. This definition also includes the offer of medical, spa and wellness tourism. Medical tourism is focused on specific medical procedures and therapies for which there must be adequate infrastructure (hospitals, clinics, professionals and equipment) with the inclusion of health tourism elements as accompanying treatments. Medical tourism has not been perceived for a long time only through the prism of patient care, but is increasingly focused on prevention and general health care and strengthening vitality. Despite differences, health and medical tourism is commonly studied together because there are numerous synergistic effects that can be achieved by providing both types of services (Madžar et al., 2016: 191).

Health tourism is one of the fastest growing specific forms of tourism in the world. This form of tourism has an annual growth of $15 \%$ to $20 \%$. The World Health Organization predicts that due to the aging population trend and the increasingly marked orientation of society to a healthy life, health care will account for as much as $22 \%$ of world GDP by 2030 and 
be the biggest driver of tourist travel. Health tourism is a complex tourist product that at the world level shows above average annual growth rate and encompasses a large number of specialized content and services offered on travel motivated by the need to improve health and quality of life (National program - Action Plan for development of health tourism of the Republic of Croatia, 2014: 8). Health tourism through its numerous subtypes, combinations and different levels and basis of treatments is not linked to the main tourist season or narrow area of a tourist destination (Jadrešić, 2001: 143). Those characteristics show that represents the lever for a steady and balanced development of the areas in which it develops. As for the motives for going to this type of travel, most often it is the difference in the prices of medical services between the emitting and receptive country. People go on the trip due to a combination of rest and recreation and the use of medical services. Additionally, to some people services in medical tourism are the only possibilities to receive adequate medical care at an affordable price (Krajnović et al., 2013: 18).

Many countries in the world have decided to exploit the potentials for the development of medical tourism. They were strategically determined and subsequently adapted the health care system so they could receive foreign patients. Most of these countries are developing countries. Patients from richer and more developed countries travel to less developed countries for access to health services. Earlier, the movement in health tourism, especially in the medical field, referred to the most advanced countries with the best technology, while today the direction of patient movement is reversed. Affordable treatments, cheap flights and a wide range of available information are also contributed to this (Madžar et al., 2016: 192).

World Association for Medical Tourism, Medical Tourism Association, MTA, is the first and an umbrella global non-profit organization for medical tourism (http://www.medicaltourismassociation.com). This organization works with healthcare professionals, governments, insurance companies and other entities that are related to medical tourism. The aim is the development of medical tourism and the provision of the highest quality and most transparent health services. MTA offers education (e.g. "Health \& Wellness Destination Guides" program), certification and other activities for the development of medical tourism.

The world's most famous journal in the area of providing services in medical tourism, "International Medical Travel Journal" (IMTJ), was founded in 2007, works on the development and improvement of medical tourism in the world, envisages a growth between 5 and 7 billion US dollars a year (https://www.imtj. com). The last five years medical tourism in the world has stagnated, about 7 million people travel motivated by health reasons. Domestic medical tourism is on the rise and in this sphere of medical tourism travels around 3 million people, while health and wellness grows year by year and reaches a number of 50 million people.

The report „Medical Tourism Facts and Figures 2016 " by I. Youngman concluded that medical tourism is a more local and regional product than global and that the medical form of tourism, as well as the overall tourism, is affected by politics and fear of terrorism in the world (https://www.imti.com/articles/medicaltourism-2016-what-has-changed/). It also concluded that the "tourism industry" ignores medical tourism, and health tourism as well which is an integral part of medical tourism. Good results in medical tourism are achieved United Kingdom, USA, Germany, Switzerland, South Korea, Dubai, Malaysia and Iran. Thailand, Turkey, Egypt, Finland and Tunisia are experiencing poorer results, and this is happening with Singapore, Israel, Jordan and Brazil. Israel and South Africa show the highest resistance to tourist arrivals in the field of medical tourism, while Nigeria and Kenya lead African states in an effort to reduce departures from the country motivated by health reasons. India, United Kingdom and USA are aware that medical tourism at national level is equal or even more important than international (Ibid.).

IMTJ is a very influential link in the development of medical tourism, organizing every time more visited events that bring together experts from around the world, namely: IMTJ Medical Travel Summit, IMTJ Medical Travel Awards and The Private Healthcare Summit. Their award in the category of the best tourist destination in the world in 2016 was received Malaysia. The IMTJ Medical Travel Summit was held from 24 to 26 May, 2016 in Madrid, and gathered 350 participants from more than 45 countries, while a year earlier in London gathered 130 participants from 40 countries (https://www.imti.com/what-we-do/).

The Republic of Croatia, and the City of Opatija, hosted the IMTJ Medical Travel Summit in 2017, organized by Intuition Communication from the United Kingdom (http://hrturizam.hr/opatija-domacinimtj-medical-travel-summita-2017/). The objective was to use the IMTJ Medical Travel Summit to brand Kvarner, but also the Republic of Croatia as a destination of health. Statistically, the Summit is attended by $78 \%$ participants from Europe, $10 \%$ from Asia, 6\% from the Middle East and North Africa, 4\% from North America and 2\% from other countries. $46 \%$ of participants come as representatives of hospitals and clinics, while Summit brings together $11 \%$ of the medical-tourism facilitators, $9 \%$ of representatives of educational institutions, $6 \%$ of marketing experts, rep- 
resentatives of public authorities and representatives of providers of health related services. Other participants come from tourist boards, insurance companies and media houses.

Analyzing the current development of health tourism on the territory of the Republic of Croatia, it was found that the commencement was recorded at the end of the 19th and beginning of the 2oth century in places with healing properties (bathing places, medicinal/ healing water places, climate spas, places with healing mud). Users of health and tourism services at that time were mostly foreigners from more developed European countries. The pioneer in Croatian health tourism is the island of Hvar. On the island of Hvar, in 1868, the Hygienic Society of Hvar was founded (Zaninović, 2003: 283). After that, in 1889, the Austrian government officially proclaimed the City of Opatija as the first climatic seaside resort on the Adriatic. Thalasotherapy Opatija, a special hospital for the rehabilitation of heart, lung and rheumatism, was founded in 1957 and today is the leader of health tourism in the Republic of Croatia. The fact that income/revenue from health tourism is only $1 \%$ of the total tourist revenues of the Republic of Croatia is, with regard to the potentials, very worrisome. According to the data published so far, there are 222 sites in the Republic of Croatia with favorable potential conditions for the development of health tourism, of which only $10 \%$ are exploited within 18 organized health centers (Geić, 2011: 239).

Like other Mediterranean countries, so the Republic of Croatia swept wave wellness centers that offer medical and other treatments for health care and preservation of health. Over the last 15 years, more than 90 hotels have developed an integrated wellness offer. The total accommodation capacity units of health tourism participate with a slight $0,5 \%$. These health-tourism facilities are mainly concentrated in the coastal and northwestern parts of the Republic of Croatia, in Istria, Kvarner, the northern part of the Republic of Croatia and in the area of the City of Zagreb (National program - Action Plan for development of health tourism of the Republic of Croatia, 2014: 12). The offer is based on providers of wellness, spa and medical services in the private and public sectors. A significant part of the offer of all forms of health tourism is privately owned, market-oriented, vibrant and small-medium entrepreneurship.

In the Republic of Croatia, about 10,000 employees realize about 300 million euros of revenues from health tourism services without included the value of overnight stays. However, the rough estimate is that health tourism in the Republic of Croatia has an annual potential revenue of one billion euros. In other words, the share of health tourism in total tourism income, that all the measures and activities defined in the Strategy for development of tourism of the Republic of Croatia until 2020, i.e. the Action Plan for development of health tourism of the Republic of Croatia were implemented have increased from $2 \%$ in 2013 to 15\% in 2020 (Milas, 2015: 3 ).

\section{Discussion}

\section{Priority measures for improving the competitiveness of Croatian tourism as defined by the Strategy for development of tourism of the Republic of Croatia until 2020}

Strategy for development of tourism of the Republic of Croatia until 2020 is the umbrella development document of Croatian tourism, which represents the direction for tourism development (Strategy for development of tourism of the Republic of Croatia until 2020, 2013). The pronounced economic and political instability at the global level and in the European Union, new conditions of the Croatian macro environment and dynamic changes in relation to consumer demands in the global tourism market, have necessitated a revision of the tourism development model in the Republic of Croatia with the purpose of devising development guidelines and operational strategies. Strategy for development of tourism of the Republic of Croatia until 2020 answered the question of what kind of tourism the Republic of Croatia should develop, and it identifies key tourism policy activities aimed at ensuring production, institutional, organizational and human conditions for improving the competitiveness of Croatian tourism and using the resource base on the responsible and sustainable development principles (Ibid.). As this is a document that should ensure the integration of the Republic of Croatia into the consolidated tourism policy of the European Union, the Strategy for development of tourism of the Republic of Croatia until 2020 is a complete conceptual framework that enables:

- Coordinated action of tourism policy makers,

- Systematic harmonization of tourism policy measures,

- Comprehensive understanding of the key trends in the development of Croatian tourism as a precondition for attracting the interests of potential domestic and foreign investors, and

- Targeted routing of the development and investment process and the effective withdrawal of EU 
Table 1. Priority measures for improving the competitiveness of Croatian tourism

\begin{tabular}{|c|c|}
\hline Measure number & Name of measure \\
\hline Measure 1 & $\begin{array}{l}\text { Harmonization and improvement of the legislative framework in order to strengthen entrepreneurship and } \\
\text { investment }\end{array}$ \\
\hline Measure 2 & The acceleration of investment activity by adopting a special law \\
\hline Measure 3 & The prompt resolution of property ownership issues \\
\hline Measure 4 & Development and implementation of privatization program of state-owned tourism enterprises \\
\hline Measure 5 & Economic activation of tourist facilities/sites managed by the Agency for State Property Management \\
\hline Measure 6 & Proactive fiscal policy in tourism \\
\hline Measure $7^{*}$ & $\begin{array}{l}\text { Launching new programs to encourage development of small, medium and large-scale entrepreneurial } \\
\text { ventures in tourism }\end{array}$ \\
\hline Measure $8^{*}$ & National Program for development of small family hotels \\
\hline Measure $9^{*}$ & National Program for promotion of family accommodation \\
\hline Measure 10 & Creating entrepreneurial clusters \\
\hline Measure 11 & $\begin{array}{l}\text { The definition of common criteria for strategic planning of tourism development and development of } \\
\text { strategic plans for development of tourism in the county/local level }\end{array}$ \\
\hline Measure $12 *$ & Regional/local programs of beach planning and management \\
\hline Measure $13^{*}$ & Action Plan for development of nautical tourism - yachting \\
\hline Measure $14^{*}$ & Action Plan for development of health tourism \\
\hline Measure $15^{*}$ & Action Plan for development of cultural tourism \\
\hline Measure $16^{*}$ & Action Plan for development of the congress offer \\
\hline Measure $17^{*}$ & Action Plan for development of golf offer \\
\hline Measure 18 & Program for development of cyclotourism \\
\hline Measure 19 & Harmonization of education in the hospitality industry with demand \\
\hline Measure $20 *$ & National lifelong learning program for tourism professionals \\
\hline Measure 21 & $\begin{array}{l}\text { Reorganization of the system of tourist boards and building an efficient system of tourism destination } \\
\text { management }\end{array}$ \\
\hline Measure 22 & Creating a new strategic marketing plan of Croatian tourism \\
\hline Measure 23 & Development program of specialization of receptive tourism agencies \\
\hline Measure 24 & Continuous production of TSA (Tourism Satellite Account) and regional TSAs \\
\hline Measure 25 & Promotion of investment in tourism \\
\hline Measure 26 & $\begin{array}{l}\text { Positioning of the Ministry of Tourism Republic of Croatia as an intermediary body in the operational } \\
\text { structure for managing the process of using EU funds } 2014-2020\end{array}$ \\
\hline
\end{tabular}

*Additionally funded Action Plans for the implementation of specific forms of tourism.

Source: Strategy for development of tourism of the Republic of Croatia until 2020, 2013: 67-69.

funds (Strategy for development of tourism of the Republic of Croatia until 2020, 2013: 3-4).

Strategy for development of tourism of the Republic of Croatia until 2020 in the final part of the document refers to the implementation of the defined vision and strategic development goals. Emphasis is placed on operational strategies in key areas of activity. These are activities focused on product development, accommodation and tourism infrastructure, investments, marketing, human resources building and tourism development management (Strategy for development of tourism of the Republic of Croatia until 2020, 2013: 4). Action Plan of the Strategy for development of tourism of the Republic of Croatia until 2020 implementation contains
26 priority measures for improving the competitiveness of Croatian tourism with envisaged dynamics of implementation, the main goal of which is to establish strategic guidelines for concerted action of major tourism and economic policy-makers at the national level in order to enhance the competitiveness of Croatian tourism (Ibid.).

From the foregoing, it is evident that all the measures of tourism policy, namely Measures 7, 8, 9, 12, 13, 14, 15, 16,17 and 18 which includes action plans/national programs of the Strategy for development of tourism of the Republic of Croatia until 2020 were listed as a key action areas that need to be taken into account when implementing the Strategy. On the other hand, „sun and sea" is still the dominant tourist product of the Republic of Croatia. This will remain in the future if its posi- 
tion on the Mediterranean market is not continuously improved through substantially enriching and increasing the quality of the accommodation and service offer, i.e. deepening the destination value chain. Today's dominant position of „sun and sea“ product is at the same time the main reason for the pronounced seasonality of tourist demand and the concentration of tourist traffic on the narrow coastal zone of the Republic of Croatia. In this respect, reliance on the product „sun and sea" will not contribute in the long run to a significant improvement of the competitive position of the Republic of Croatia as a tourist destination, and thus to neither increase of tourist consumption nor better use of development potentials. In the period from 2013 to 2020, the Republic of Croatia should turn more intensively to the development of tourism products, which should have enabled greater utilization of available capacities outside the summer months and activation of the tourism potential of continental Croatia (Strategy for development of tourism of the Republic of Croatia until 2020, 2013: 36).

The structure of tourism products in the Republic of Croatia in the last ten years has changed only to a small extent, and this indicates just seasonality curve. Starting from the existing features of the Croatian tourist offer, but also from the qualitative features of the Croatian tourist attraction, the Strategy for development of tourism of the Republic of Croatia until 2020 defined the key production groups on which the system of tourism products of the Republic of Croatia should be built by 2020, and one of them are health tourism. Such a diversified system of tourist products enables the Republic of Croatia to expand to the structure of the segments of visitors whose preference for different types of travel, different price positions and trips in different periods of the year opens the possibility of a significant time extension of tourist activity and increase tourist consumption. Furthermore, further production diversification of basic tourist experiences system, which implies the commercialization of individual products, opens the possibility of dispersion of tourist activity to the entire territory of the Republic of Croatia. In this way, it is possible to gradually reduce today's uneven dispersion of the effects of tourism activity in the Republic of Croatia.

Priority measures of tourism policy defined by the Strategy for development of tourism of the Republic of Croatia until 2020 are divided into two categories:

1. The first category (the highest priority) consists of measures without which the initiation and/or implementation is not possible to realize the defined strategic goals/objectives, i.e. Measures 1, 2, 3, 4, 5, 6, 21 and 26, which were to be implemented during 2013.

2. The second category (medium high priority) consists of measures that are essential for the achieve- ment of individual development goals, these are Measures 7, 8, 9, 10, 11, 12, 13, 14, 15, 16, 17, 18, 19, 20, 22, 23, 24 and 25 and should have been carried out for the most part in the period from 2013 to 2015, or in the case of unexpected circumstances in the period from 2016 to 2020. All tourism policy measures defined in the Strategy for development of tourism of the Republic of Croatia until 2020 and related to the implementation of action plans/national programs are medium high priority measures, and these are Measures 7, 8, 9, 12, 13, 14, 15, 16, 17,18 and 20 (Strategy for development of tourism of the Republic of Croatia until 2020, 2013: 66).

In the period from 2013 to 2015 , the following programs were presented to the public:

1. National Program for development of small and medium-sized enterprises in tourism,

2. National Program for improving the offer of small and family hotels,

3. National Program the promotion of family accommodation,

4. National Program of management and regulation of beaches,

5. Action Plan for development of nautical tourism,

6. Action Plan for development of health tourism,

7. Action Plan for development of cultural tourism,

8. Development of cycling tourism,

9. Program for strengthening the competitiveness of human resources in tourism (centers of competence),

10. National Program for the development of social tourism, and

11. Action Plan for development of green tourism (https://mint.gov.hr/istaknute-teme/strategija-razvojaturizma-11411/akcijski-planovi-15525/15525).

On December 6, 2016, the public was presented the National Program - Action Plan for development of congress tourism (https://mint.gov.hr/UserDocsImages/AA 2018 c-dokumenti/akcijski\%2oplanovi/o01 170120 akc p kongres.pdf), and in the first quarter of the year 2018 Action Plan for development of golf offer_https://mint.gov.hr/UserDocsImages/ AA 2018 c-dokumenti/180125 akcijski golf.pdf).

The mentioned action plans/national programs elaborated activities for the implementation of certain priority measures to improve the competitiveness of Croatian tourism, their holders and deadlines for implementation. The internal organizational units of the Ministry of Tourism of the Republic of Croatia, which, according to the Strategy for development of tourism of the Republic of Croatia until 2020 are responsible for the implementation of certain measures of tourism policy, should take the above into consider- 
ation when planning implementation activities of the Draft Annual Action Plan for the implementation of the Strategy for development of tourism of the Republic of Croatia until 2020 in the framework of the interministerial working group for the implementation of tourism policies that are defined by the Strategy.

Coordination of those responsible for the implementation of action plans/national programs in the Ministry of Tourism of the Republic of Croatia with other state administration bodies and other competent institutions has proven to be crucial of which depends effective implementation. Despite successful examples of effective coordination and cooperation, the fact is that some measures, such as Action Plans of cyclotourism, rural, green and health tourism, could be significantly more effectively implemented in the context of more successful coordination, both within the Ministry of Tourism of the Republic of Croatia itself and between the relevant related ministries (Evaluation in the course of implementation of the Strategy for development of tourism of the Republic of Croatia until 2020 (interim evaluation), 2017: 25).

It is also important to emphasize that effective strategic development management requires a flexible mechanism that provides the necessary information and promotes the results of implementation. In addition to controlling activities, a model for measuring (monitoring and evaluating) developmental effects of strategic planning acts, regardless of their content, is important, since it represents one of the policy frameworks, in this case tourism policy, which must be based on a system of measurable indicators effect. Implementation activities should be elaborated to contain clearly defined indicators for measuring the impact of strategic documents on development, and evaluation of the success for achieving the set objectives and the relevance and reality of the planned activities within the priorities and measures.

As already pointed out, the Strategy for development of tourism of the Republic of Croatia until 2020 envisaged diversification of products, e.g.: Measure 13 - nautical tourism, Measure 14 - health tourism, Measure 15 - cultural tourism, Measure 16 - congress tourism, Measure 17 - golf offer and Measure 18 - cyclotourism (Strategy for development of tourism of the Republic of Croatia until 2020, 2013: 35) in order to influence the extension of the tourist season and expanding geographic base, and consequently the increase of consumption, provided that the action plans implemented by the defined dynamics of implementation. Additionally funded and developed action plans for specific forms of tourism, some of which have not yet been adopted, are not being implemented, or are only being implemented to a small extent (Evaluation in the course of implementation of the Strategy for de- velopment of tourism of the Republic of Croatia until 2020 (interim evaluation), 2017: 5, 18). Seasonality is still high, although the diversified tourism products do not depend on the season.

In view of all the above, there is a significant gap between the current position and the one planned in relation to the set goals, defined by the Strategy for development of tourism of the Republic of Croatia until 2020 and the Action Plan for the implementation of the Strategy for development of tourism of the Republic of Croatia until 2020 (Strategy for development of tourism of the Republic of Croatia until 2020, 2013: 66-85). Namely, the main objective defined by the Strategy for development of tourism of the Republic of Croatia until 2020 is to increase the attractiveness and competitiveness of tourism, which should have resulted in the entry of the Republic of Croatia among the 20 leading tourist destinations in the world by the year 2020 according to the criteria of competitiveness (WEF - World Economic Forum) (Strategy for development of tourism in the Republic of Croatia until 2020, 2013: 31). Based on the Travel \& Tourism Competitiveness Report, Republic of Croatia is currently in 32nd place. (The Travel \& Tourism Competitiveness Report 2017. Paving the way for a more sustainable and inclusive future, 2017) By comparing the results of Travel \& Tourism Competitiveness Report from May 2015 (http://konkurentnost. hr/hrvatska-medu-turisticki-najkonkurentnijim-zemljama-svijeta/) and May 2017 (The Travel \& Tourism Competitiveness Report 2017. Paving the way for a not sustainable and inclusive future, 2017), there has been little progress made by the Republic of Croatia according to the criteria of competitiveness (WEF - World Economic Forum), since in 2015 the Republic of Croatia was ranked on the 33th place, and in 2017 at 32nd.

From the above it can be concluded that at this rate of progress cannot expect the fulfillment of the main objective/goal defined by the Strategy for development of tourism in the Republic of Croatia until 2020, which is related to increasing the attractiveness and competitiveness of tourism, and should result in the entry of the Republic of Croatia into 20 leading tourist destinations in the world by 2020 , according to the WEF criteria of competitiveness (Strategy for development of tourism of the Republic of Croatia until 2020, 2013: 31). In addition to the main objective, other strategic goals have been defined that relate to improving the structure and quality of accommodation, new employment, investments and increase tourism spending (Ibid.).

\section{Action Plan for development of health tourism of the Republic of Croatia}

In addition to a detailed analysis of the competitive position, the Action Plan for development of health tourism identifies priorities for upgrading the offer/ 
services of existing thermal/thalassotherapy destinations/institutions as well as destinations/institutions of wellness and medical tourism and identifies priority locations/sites for the construction of new facilities of health tourism offer (Strategy for development of tourism of the Republic of Croatia until 2020, 2013: 78). The Action Plan for development of health tourism in- cludes development of health tourism concept proposal and best use of appropriate business-management model (Ibid.). The Plan specifically elaborates activities related to staff training, networking and improving market performance (Ibid.).

The Action Plan for development of health tourism also elaborates the activities necessary for implemen-

Table 2. Action Plan for development of health tourism: implementation activities and holders of activities

\begin{tabular}{|c|c|c|}
\hline $\begin{array}{l}\text { Ordinal } \\
\text { number }\end{array}$ & Implementation activities & Holder(s) of activities* \\
\hline \multicolumn{3}{|c|}{ Fields of activity and programs for raising the competitiveness of the wellness sphere } \\
\hline 1 & Regulation of holistic and medical wellness services & MHRC / MTRC \\
\hline 2 & International certification & MTRC and MHRC \\
\hline 3 & Improvement of existing offer & MTRC and MRDEUFRC \\
\hline 4 & Lifelong education of employees & MSERC, MTRC, MHRC \\
\hline 5 & Adaptation of education system to the needs of wellness tourism & MTRC and MRDEUFRC \\
\hline 6 & Promotion and sales & CNTB \\
\hline 7 & Thematic/production joining & MTRC and MHRC \\
\hline \multicolumn{3}{|c|}{ Fields of activity and programs for raising the competitiveness of the sphere of health tourism } \\
\hline 1 & Expansion of activities of special hospitals (registration) & MHRC \\
\hline 2 & $\begin{array}{l}\text { Ownership, organizational and market restructuring spas/special hospitals in public } \\
\text { domain }\end{array}$ & MHRC \\
\hline 3 & Specialization - thematic profiling & MHRC and MTRC \\
\hline 4 & Improvement of existing offer & MHRC and MTRC \\
\hline 5 & Development of a new health-spa offer & MHRC and MTRC \\
\hline 6 & Operationalization of the Croatian system of accreditation of health institutions & MHRC \\
\hline 7 & International certification & MHRC \\
\hline 8 & Lifelong education of professionals in spas/hospitals & MSERC and MTRC \\
\hline 9 & Adaptation of educational system to the needs of health tourism & MSERC, MHRC and MTRC \\
\hline 10 & Thematic/production joining & MTRC and MHRC \\
\hline 11 & Promotion and sales & CNTB, MTRC and MHRC \\
\hline 12 & Linking with international spa tourism facilitators & MTRC and MHRC \\
\hline 13 & Statistical monitoring of spa (health) tourism effects & MTRC and MHRC \\
\hline 14 & National Institute of Balneology & MHRC \\
\hline 15 & Certification of Croatian health resorts & MTRC and MHRC \\
\hline \multicolumn{3}{|c|}{ Fields of activity and programs for raising the competitiveness of the medical tourism sphere } \\
\hline 1 & $\begin{array}{l}\text { Operationalization of the Croatian accreditation system for all health care } \\
\text { institutions }\end{array}$ & MHRC \\
\hline 2 & International certification & MHRC \\
\hline 3 & Improving the quality of public sector offer in the field of medical tourism & MHRC \\
\hline 4 & $\begin{array}{l}\text { Improving the depth and breadth of private sector offer in the field of medical } \\
\text { tourism }\end{array}$ & MHRC and MTRC \\
\hline 5 & Thematic/production association of private medical tourism providers & MHRC and MTRC \\
\hline 6 & Promotion and sale of medical tourism services in the public sector & CNTB, MTRC and MHRC \\
\hline 7 & Promotion and sale of medical tourism services in the private sector & MTRC and MHRC \\
\hline 8 & Linking with international facilitators of medical tourism & MTRC and MHRC \\
\hline
\end{tabular}

Source: National program - Action Plan for development of health tourism of the Republic of Croatia, 2014: 36-69.

*Explanation of abbreviations: MHRC - Ministry of Health of the Republic of Croatia, MTRC - Ministry of Tourism of the Republic of Croatia, MRDEUFRC - Ministry of Regional Development and EU Funds of the Republic of Croatia, MSERC - Ministry of Science and Education of the Republic of Croatia, CNTB - Croatian National Tourist Board 
tation of the selected projects and holders of activities, as shown in Table 2 (National program - Action Plan for development of health tourism of the Republic of Croatia, 2014: 36-69).

\section{Programs in the function of increasing the competitiveness of health tourism in the Republic of Croatia}

Recognizing the potential, Strategy for development of tourism of the Republic of Croatia until 2020 (2013) envisages further development of health tourism, i.e. all its modalities. The Strategy positions spa tourism as a carrier or "core" of the health and tourism offer of the Republic of Croatia, with the assumption of ensuring the differentiation of health resorts and the importance of raising their quality. In this connection, a combination of thalassotherapy and continental spas offerings is assessed as a strategic advantage in the narrower competitive circuit. The basis for further development of medical tourism comes from the improvement of the quality of offer, increased communication and sales efforts, and the networking of the Republic of Croatia with the health insurance systems of other European Union member states.

Also, based on the recognized comparative advantages of the Republic of Croatia in the SWOT analysis, strategic national documents Strategy for development of tourism of the Republic of Croatia until 2020 (2013) and National strategy for development of healthcare of the Republic of Croatia 2012-2020 (2012), stress further development of the mentioned forms of tourism. Both strategies served as a base for the development of the Action Plan for development of health tourism of the Republic of Croatia (2014) as an interdepartmental platform for the systematic raising of the competitiveness of the health-tourism offer of the Republic of Croatia. The Action Plan for development of health tourism of the Republic of Croatia (2014) focuses specifically on the need to adapt:

- Existing health framework, i.e. the necessity of ownership transformation (attracting new capital, withdrawing capital from European Union funds),

- Creating highly educated staff of health-tourism providers,

- Certification of spas/special hospitals and

- Business associating.

The Action Plan for development of health tourism of the Republic of Croatia proposes thirty development activities or programs specifically aimed at:

- Improvement of the institutional framework,

- Improvement of international recognition of the Republic of Croatia as a health-tourist destination,

- Product development and specialization,
- Improvement of the quality of health tourism products, and

- Improvement of professional and managerial skills of health tourism workers (National program - Action Plan for development of health tourism of the Republic of Croatia, 2014: 34).

The proposal of the program in order to increase the competitiveness of health tourism of the Republic of Croatia in the international market implies the implementation of certain equivalent activities carried out in all three health tourism modalities - wellness, spa/health care and medical tourism, but it is necessary to implement programs aimed at each specific segment of health tourism. Also, the document lists similar activities carried out in two or three segments of health tourism, which are primarily focused on the implementation the program of building the whole system, which are:

- Accreditation of Croatian health institutions, which should ensure the establishment/protection of a minimum acceptable service/quality of health services, all with the aim of increasing the safety and user satisfaction,

- International certification of Croatian health institutions, which should ensure their greater international credibility, thereby accelerating the acquisition of greater market recognition,

- Education of employees by introducing a lifelong education obligation or adapting the Croatian education system, which should ensure greater quality and innovation of the Croatian health-tourism offer, and

- Marketing and promotion of Croatian health tourism which should be designed taking into account the different market readiness of certain types of Croatian tourism and today's degree of recognition of various health-tourism products and service providers (Ibid.).

Each modality defines specific objectives and priorities depending on their competitive abilities and the level of market readiness. The development vision of medical tourism points to the following strategic priorities:

- Improving international recognition of selected institutions through international certification,

- Improving the international desirability of the Republic of Croatia as a destination for medical tourism by establishing an effective competition/communication strategy,

- Extending the depth and breadth of the offer to the market ready medical services, and

- Enriching the existing offer with additional facilities appropriate to the needs of various segments of 
potential users of medical, health and recreational services.

In addition to modernization and construction of diagnostic and therapeutic centers, this is especially true for raising the quality of accommodation capacities (equalization with hotel standards of higher category), as well as on arranging/building a certain number of entertaining contents (sports, "water fun" and the like). Also, with several new health-tourism centers, the offer of existing spas should be complemented by the construction of new hotels that would allow equal access to natural healing factors. When constructing new facilities, special attention must be paid to the environment and ambient features of the premises (Strategy for development of tourism of the Republic of Croatia until 2020, 2013: 39).

Priority product development activities comprise:

- Implementation of Action Plan for development of health tourism of the Republic of Croatia in cooperation of the Ministry of Tourism of the Republic of Croatia and Ministry of Health of the Republic of Croatia,

- Establishment of minimum standards for wellness centers, health/spa tourism centers and medical tourism centers, including standard of furnishing, security, quality of service and environmentally responsible "green business", and

- Croatian health/spa destinations should strategically connect and/or network with internationally identifiable and established health and medical tourism providers in the countries of the relevant competitive circle, e.g. with Austria, Italy, Germany, Hungary, Slovenia (Strategy for development of tourism of the Republic of Croatia until 202O, 2013: 40).

With the mutual cooperation of the Ministry of Health of the Republic of Croatia, the Ministry of Tourism of the Republic of Croatia and the Ministry of Labor and Pension System of the Republic of Croatia planned to develop an expert analysis that would identify the activities lacking human resources for the further development of health tourism. In cooperation with the Ministry of Science and Education of the Republic of Croatia, the registration quotas were planned to be corrected for certain orientations of future experts in this area by adapting curricular programs planned to educate a quality staff according to new needs on the market.

Statistical monitoring of business and customer satisfaction is a key prerequisite for efficient policy management in the sphere of health tourism and for international comparisons of the achieved level of products competitiveness. In the Republic of Cro- atia there are still insufficient and sufficiently credible data on the basic features of the business and customer satisfaction of the services of health tourism providers. Such a situation makes it substantially difficult to make development decisions, and thus the management of the development process (National program Action Plan for development of health tourism of the Republic of Croatia, 2014: 56).

The interdisciplinary relationship in health tourism often creates certain difficulties in the development of this sector. Therefore, the complexity of the relationship and the lack of compliance with applicable legislation and subordinate legislation (regulations) between the Ministry of Health of the Republic of Croatia and the Ministry of Tourism of the Republic of Croatia, directly competent in this segment, and directly related to the Ministry of Culture of the Republic of Croatia and the Ministry of Regional Development and EU Funds of the Republic of Croatia. The Ministry of Culture of the Republic of Croatia has an important role in the development of health tourism, because a large number of health resorts/spas and special hospitals in the Republic of Croatia are located in attractive natural locations, which are mainly protected cultural goods.

\section{Programs in the function of increasing the competitiveness of medical tourism in the Republic of Croatia}

In the Action Plan for development of health tourism of the Republic of Croatia there are eight operational programs for the development of competitiveness in the sphere of medical tourism, fifteen operational programs in the field of health/spa tourism and seven operational programs related to wellness tourism. Each of the programs for wellness tourism refers to both medical and holistic wellness (National Program - Action Plan for development of health tourism, 2014: 68).

The predictable dynamics of the implementation of the proposed programs to raise competitiveness in the field of medical tourism, i.e. their priority is detailed presented in Table 3.

Out of a total of eight operational programs to increase the competitiveness of medical tourism from four first priority programs, three programs related to the improvement of the depth and breadth of the private sector offer in the sphere of medical tourism (Program 4), promotion and sale of medical tourism services in the private sector sphere (Program 7) and linking to international facilitators of medical tourism (Program 8) were to be carried out during 2015. International certification (Program 2) was to be carried out during 2015 and at the latest by the end of 2016 . Two programs of the second priority programs, which relate to the operationalization of the Croatian ac- 
Table 3. Time dynamics and priority of the programs to raise the competitiveness of medical tourism

\begin{tabular}{|c|c|c|c|c|c|c|c|}
\hline \multirow{2}{*}{ Programs in the function of increasing competitiveness } & \multirow{2}{*}{ Priority } & \multicolumn{6}{|c|}{ Year of medical tourism } \\
\hline & & 2015 & 2016 & 2017 & 2018 & 2019 & 2020 \\
\hline $\begin{array}{l}\text { Program 1: Operationalization of the Croatian accreditation } \\
\text { system of all health institutions }\end{array}$ & II & 2015 & 2016 & & & & \\
\hline Program 2: International certification & 1 & 2015 & 2016 & & & & \\
\hline $\begin{array}{l}\text { Program 3: Improving the quality of public sector offer in } \\
\text { the field of medical tourism }\end{array}$ & III & & & 2017 & 2018 & 2019 & \\
\hline $\begin{array}{l}\text { Program 4: Improving the depth and breadth of the private } \\
\text { sector offer in the sphere of medical tourism }\end{array}$ & 1 & 2015 & & & & & \\
\hline $\begin{array}{l}\text { Program 5: Thematic/production associating of private } \\
\text { providers of medical tourism services }\end{array}$ & II & 2015 & 2016 & & & & \\
\hline $\begin{array}{l}\text { Program 6: Promotion and sale of medical tourism services } \\
\text { in the public sector sphere }\end{array}$ & III & & & 2017 & 2018 & & \\
\hline $\begin{array}{l}\text { Program 7: Promotion and sale of medical tourism services } \\
\text { in the private sector sphere }\end{array}$ & 1 & 2015 & & & & & \\
\hline $\begin{array}{l}\text { Program 8: Linking to international facilitators of medical } \\
\text { tourism }\end{array}$ & 1 & 2015 & & & & & \\
\hline
\end{tabular}

Source: National Program - Action Plan for development of health tourism of the Republic of Croatia, 2014: 69.

creditation system of all health institutions (Program 1) and thematic/production associating of private providers of medical tourism (Program 5), should have been carried out during 2015 and at the latest by the end of 2016. Priority Program 3 to improve the quality of the public sector offer in the field of medical tourism was to be carried out during 2017, 2018 and no later than 2019, while the program of promotion and sale of medical tourism services in the public sector sphere (Program 6) was to be carried out during 2017 and 2018.

Programs in the function of increasing the competitiveness of medical tourism did not implement the expected time dynamics of implementation and/ or were not implemented at all, which also affects the none/effectiveness of the implementation of the Action Plan for development of health tourism of the Republic of Croatia, and then the overall Strategy for development of tourism of the Republic of Croatia until 2020. From the obtained results based on the Evaluation in the course of implementation of the Strategy for development of tourism of the Republic of Croatia until 2020, from December 2017, conducted by the Institute for Development and International Relations, IRMO, from Zagreb (Service evaluation in the course of implementation of the Strategy for development of tourism of the Republic of Croatia until 2020 (interim evaluation), 2017), it can be concluded that the relevance of the Strategy is not questionable, i.e. it is relevant and on all grounds. However, judging by key stakeholders, the majority of the action plans adopted in the implementing/practical sense are irrelevant, as the action plans are implemented only partially, or are not implemented at all. The reasons why in the observed period all planned were not realized are:
- Insufficient number of expert and competent officers on the implementation of medical programs as part of the implementation of the Action Plan for development of health tourism of the Republic of Croatia,

- Insufficient financial resources and dependence on external sources of financing,

- An insufficient number of conscious stakeholders in individual measures, and

- Slow and inefficient inter-ministerial cooperation.

Coordination of responsible for the implementation of the Measure 14 of the Action Plan for development of health tourism of the Republic of Croatia from the Ministry of Tourism of the Republic of Croatia with other State administration bodies and other competent institutions proved to be crucial of the effective implementation. Despite successful examples of effective coordination and cooperation, the fact is that some measures (for example, action plans for cyclotourism, rural, green and health tourism) could be substantially more effective implemented under better coordination conditions within the Ministry of Tourism of the Republic of Croatia and between the relevant related ministries. In view of this, the Ministry of Tourism of the Republic of Croatia should certainly establish better coordination with other bodies and position itself as an initiator of the implementation of all measures and activities that are primarily not under the jurisdiction of the Ministry of Tourism of the Republic of Croatia. This would also ensure an extremely significant mutual complementarity of the measures, i.e. links and mutually supportive synergic effects of measures from the Strategy with strategic documents of other ministries and sectors (Ibid.). 


\section{The economic performances}

\section{of the tourist products of medical tourism} in the Republic of Croatia

Factors influencing the decision to travel to another country for treatment usually include substantially lower costs of surgery, long waiting lists in the country of origin and the risk of low quality medical services or lack of quality health institutions in country (National Program - Action Plan for development of health tourism of the Republic of Croatia, 2014: 18). Given the most sought-after medical tourism services in Europe, which are presented in Table 4, below will be discussed more about the economic performance of medical tourism in the sphere of dentistry and cosmetic surgery.

Table 4. Most wanted medical tourism services in Europe

\begin{tabular}{|l|c|}
\hline Service type & $\begin{array}{c}\text { Demand services in } \\
\text { percentages }\end{array}$ \\
\hline Dentistry & $30 \%-50 \%$ \\
\hline Cosmetic Surgery & $25 \%-34 \%$ \\
\hline Orthopedic Surgery & $7 \%$ \\
\hline Obesity Treatments & $7 \%$ \\
\hline IVF Treatments & $3 \%-6 \%$ \\
\hline Ophthalmological Surgery & $3 \%$ \\
\hline
\end{tabular}

Source: National Program - Action Plan for development of health tourism of the Republic of Croatia, 2014: 18.

The significance and demand for medical tourism services is growing due to faster transport and more favorable transport routes, globalization, Internet use, but also following the increased cost of health services in many countries. The most common motive for the use of medical tourism services in another country are, as a rule, significant differences in the cost of using these services (Goldbach, West, 2010: 45). For example, the rates of Botox treatment differ considerably depending on the place of use of the service. Table 5 shows the average prices in euros for Botox treatment in France, Austria, Switzerland, Germany and Croatia.

Table 5. Average prices in euros of Botox treatment per country (according to www.estheticon.com)

\begin{tabular}{|l|c|}
\hline State & Average price (in euros) \\
\hline France & 422 \\
\hline Austria & 409 \\
\hline Switzerland & 490 \\
\hline Germany & 720 \\
\hline Croatia & 392 \\
\hline
\end{tabular}

Source: Krajnović et al., 2013: 19.

In Table 5 it is evident that the Croatian polyclinics, of all the above mentioned countries, had average low- est prices for Botox treatment. In the following Table 6 , the comparative prices of dental services are shown, from which it is apparent that the average price for all dental treatments in the Republic of Croatia is about $57 \%$ lower compared to prices in the United Kingdom and Ireland.

Goldbach and West state that developing countries have significantly lower cost of medical services, so medical treatments can be well combined with a luxury holiday. Comparative analysis of the prices of medical services in the countries that develop medical tourism explains the essence of the economic performance of the tourist product of medical tourism. In order to understand the economic performance of the tourist product of medical tourism should understand the motives that encourage tourists to travel to the destinations of medical tourism. Patients, in this case tourist users, most often travel to tourist destinations of medical tourism due to the lower cost of medical services (Goldbach \& West, 2010: 44).

However, there is insufficient research in this area, so it is still not possible to determine the optimal model of the economic performance of medical tourism products. Therefore, the tourist product of medical tourism is observed on a case-by-case basis, i.e. comparing individual countries and their prices of medical services. It would also be useful to explore the average and total boarding and off-board spending in destinations of medical tourism and what is the proportion of medical services in total consumption, the average duration of stay of medical tourism tourist users, which are the preferences of tourist users of medical tourism in the choice of tourist destination, hotel categories etc. Based on a sufficient number of relevant researches of this type, the optimum model of economic performance could be obtained in order to maximize the satisfaction of the users of medical tourism services, but also to maximize the profits of "tourist clinics“, hotel entities in which users reside as well as other entities in the tourist destination of medical tourism, in accordance with the principles of ethics and sustainable development (Krajnović et al., 2013: 21).

Medical tourism in the Republic of Croatia, specifically dental tourism, was significantly started to develop twenty years ago, first in the region of Istria and Primorje-Gorski Kotar County. After that, it gradually expanded to central Dalmatia and later to the City of Zagreb and the ring around the City of Zagreb. There was no systematic approach to effective strategic management of health/medical/dental tourism development in the Republic of Croatia and everything was left to private, entrepreneurial initiatives. Private initiatives focused largely on the Italian market, primarily due to proximity. Orientation towards the Italian 
Table 6. Price comparison in euros of dental services in the United Kingdom and Ireland with those in the Republic of Croatia

\begin{tabular}{|c|c|c|}
\hline & UK \& Ireland & Croatia \\
\hline \multicolumn{3}{|l|}{ RADIOLOGIA } \\
\hline •X-rays (small) & 25 & 11 \\
\hline •X-rays (panoral - full mouth) & 65 & 29 \\
\hline \multicolumn{3}{|l|}{ WHITE COMPOSITE FILLINGS } \\
\hline - Front & 140 & 45 \\
\hline - Back & 155 & 55 \\
\hline \multicolumn{3}{|l|}{ ENDODONTICS } \\
\hline - Incisor & 370 & 74 \\
\hline - Premolar & 470 & 84 \\
\hline - Molar & & 570 \\
\hline \multicolumn{3}{|l|}{ TOOTH WHITENING } \\
\hline - Airflow & 80 & 42 \\
\hline - Deep Bleaching & 789 & 280 \\
\hline \multicolumn{3}{|l|}{ CROWNS \& VENEERS } \\
\hline - Full porcelain crown & 790 & 370 \\
\hline - Tooth colored crown, metal inside & 740 & 240 \\
\hline - Bridge (dependent on design) & from 900 & 480 \\
\hline - Porcelain veneers & 720 & 325 \\
\hline \multicolumn{3}{|l|}{ EXTRACTIONS } \\
\hline - Routine & 110 & 38 \\
\hline - Surgical & 220 & 75 \\
\hline \multicolumn{3}{|l|}{ IMPLANTOLOGY } \\
\hline - Implant placement only (excluding crown) & 1.200 & 445 \\
\hline - Abutment and crown & 2.400 & 550 \\
\hline \multicolumn{3}{|l|}{ DENTURES } \\
\hline - Acrylic partial denture & 400 & 300 \\
\hline - Acrylic Denture (upper or lower) & 450 & 320 \\
\hline - Acrylic Denture (upper \& lower) & 800 & 600 \\
\hline - Cobalt Chrome (metal frame) & 1.200 & 720 \\
\hline $1-6$ teeth & 450 & 300 \\
\hline $6+$ teeth & 600 & 320 \\
\hline - Full upper or lower & 800 & 480 \\
\hline - Full upper and lower & 1.400 & 720 \\
\hline \multicolumn{3}{|l|}{ ORTODONZIA } \\
\hline - Upper and lower arch mobile & 1.800 & 400 \\
\hline - Upper and lower arch fixed (metal or white) & 4.900 & 1.900 \\
\hline - Upper arch treatment (metal or white) & 3.800 & 1.600 \\
\hline - Lower arch treatment (metal or white) & 3.500 & 1.600 \\
\hline
\end{tabular}

Source: Krajnović et al., 2013: 20

market has also occurred due to the highly developed awareness of the Italians about dental health regardless of their purchasing power and discretionary income.

In the race to earn and create additional profit, and without systematic institutional support, a large number of dental clinics, which are exclusively oriented to- wards the Italian market, in order to achieve a competitive advantage, in this case, in relation to dental service providers in Italy, reduced prices. Prices have lowered up to the level at which the Italian market is affordable to consumers with the lowest purchasing power. The aforementioned leads to the collapse of the quality of dental medicine services in these clinics, 
and thus to the creation of a generally negative image of dental/medical, and then the overall health tourism in the Republic of Croatia. For example, when installing a top quality dental implant/service, the average percentage of the complaint procedure is about $5 \%$. In contrast, in dental clinics primarily oriented towards the Italian market, the number of procedures with complaints is about $35 \%$, but it should be noted that the prices are even lower than $30 \%$ of the average prices in those clinics that provide dental service for the installation of quality dental implants. Precisely because of the large number of complaints of dental services in the clinics aimed primarily at the Italian market, which is an indispensable consequence of the low quality of materials and services, all in order to be able to attract that segment of consumers with the lowest payment power, usually they are reluctant to receive domestic patients.

Also, given the low consumer purchasing power, i.e. target segment of the market, which focuses on dental clinics operating with the Italian market, they are, as a rule, located in private accommodation and in, so-called, "rental apartments". It does not include any tourist or catering/hospitality services. In view of this, it is not possible to talk about medical/health tourism in the Republic of Croatia, which is one of the reasons that the Republic of Croatia today earns a lot less revenues than the planned defined in Action Plan for development of health tourism of the Republic of Croatia. In order to bridge the above-mentioned gap between the position of the Republic of Croatia now and the one in which it wants to be, stronger institutional support, legal regulations and, above all, measures of fiscal policy are needed in a way that aims to raising the quality of health/medical services through the price category. With such an approach, to dental medicine institutions and other medical facilities that provide a high quality service would be given the opportunity to engage in the medical/health tourism market and thus influence the raising of the competitiveness of the health tourism in the Republic of Croatia. At the same time, this would prevent further collapse of the image of dental/medical/health tourism on the emerging markets, which already has a longterm major negative impact on the competitiveness of health, as well as the overall Croatian tourism.

\section{Quality enhancement as the basis of competitive advantage in medical tourism}

When choosing a foreign health institution in which a medical procedure is intended, other than the price itself takes account of the professional accreditation (medical certificate) of the institution, doctor's experience, the percentage of successful cure or performed procedures and the provision of medical care in the home country in the event of any postoperative complications. For the user, the greatest threat to the use of medical services in another country is the possible uncertainty, i.e. the possibility of obtaining inadequate health services in relation to the expected. Research shows that this factor does not cause a decline or stagnation of medical tourism due to the present trend of the increasing standardization of the quality of medical services globally, with the use of the latest knowledge and state-of-the-art technology in the field of medicine. Additionally, many physicians who are employed in clinics in less developed countries have conducted part of their education or part of their work experience in developed countries (Turner, 2007: 314). All this does not diminish the need for a precise definition of quality standards in medical tourism at the international level, which appears as a necessity, and will be further discussed below. Despite the standards, it should be noted that the risks in medical tourism cannot be completely excluded because patients have a certain risk of complications after international treatments, since soon after surgery they are on the road, and there are dangers of infectious diseases in some countries, e.g. in India.

Often lower costs of medical services mean lower quality of these services (Turner, 2007: 313). Since not all medical institutions follow the same standards of quality, and there is a lower quality service offering due to low prices, there is an increasing need for standardizing the quality of medical services in the world. The most famous and most significant global/ world organization, which is engaged in quality monitoring and accreditation of clinics that provide medical tourism services, is Joint Commission International (JCI). The World Health Organization (WHO) also participates in the process of accreditation and certification of healthcare institutions. Such institutions are involved in regulating and overseeing the quality of the provision of medical services at international level. Other important international institutions engaged in regulating the activities of providing international health services, with the aim of ensuring the safety and satisfaction of the users of medical tourism provided by the service are: ISQUA - The International Society for Quality in Health Care and NCQA - National Committee for Quality Assurance (Krajnović et al., 2013: 25) and MTQA - Medical Travel Quality Alliance. The OECD Initiative (Organization for Economic Cooperation and Development) is also important in this field which refers to defining the so-called HCQI (Healthcare Quality). The aim is to define international quality standards that will take into account the needs of medical service users, the effectiveness of providing medical services, user safety and the degree to which the users of services in medical tourism meet. 
With this aim a commission was established consisting of representatives of more than twenty countries. This initiative has been introduced due to the insufficiently defined and unequal standards of medical services at international level and aims to introduce a quality system in medical tourism. The World Health Organization Initiative, which takes care of the safety of the users of medical services at the international level, is also launched with the same aim, but also ensures the "monitoring" of providing services in international tourism. Some countries have established their own quality assurance institutions, e.g. Germany, TEMOS101; Canada, Accreditation Canada International (http://healthstandards.org/).

The Republic of Croatia is part of one of the most developed regions of health tourism in Europe. It is surrounded by very strong competitors in the field of providing health tourism services. By studying the ways in which the destinations function, which are successful in providing services in the field of health tourism, it has been noted that great attention is paid to the integration of offer, quality, specialized sales and promotion and continuous investment. In the immediate surroundings, the competitors to the Republic of Croatia represents Slovenia, Hungary and Austria, which in addition to the long tradition of health tourism have been investing significantly in this form of tourism for twenty years.

Health tourism, and especially medical tourism, becomes a focus in a wider environment, with competitors from Turkey, Poland, the Czech Republic, Romania and Bulgaria. In the widest sense, competitors are all countries that nurture and develop medical tourism in the world. As far as competitors in the wider surroundings are concerned, it should be noted that Poland and the Czech Republic have significantly increased the quality of their medical institutions/facilities using European Union funds. With the perceived good quality of medical services, essentially lower prices than those in Western Europe (even ranging from $50 \%$ to $70 \%$ ) and with the promotion guided on national level (EU financed Polish Medical Tourism Promotion Consortium, Czech Republic - Medicaltourism.cz) they are positioned as new European centers for plastic surgery, dentistry, orthopedics and IVF, and their target markets are patients from the United States, United Kingdom, Germany and Russia.

Turkey as a provider of medical tourism represents a country that invests equally strongly in facilities, quality of service and recognition, and today has the most prestigious JCI certificates for hospitals in $\mathrm{Eu}-$ rope. Romania, Bulgaria and Serbia can count on potential future competitors in the health tourism market based on their resource bases and traditions. Their potential for now is neither developed nor internation- ally recognized, but are highlighted by the features that are important for the development of this form of tourism. Romania has about 3000 thermal and mineral springs in 70 health/spa destinations, Bulgaria is a country with a large number of mineral springs and many kinds of medicinal plants/herbs, and Serbia has a tradition of thermal spas (National Program - Action Plan for development of health tourism of the Republic of Croatia, 2014: 19-20). Increasing competition in the European receptive market to Croatian tourism sets the task of forming an offer that will attract potential tourists from the competition (Gržinić \& Bevanda, 2014: 176). An offer that is not capable of adjusting to changes in quality, adapts to demand mainly through the cost of services, resulting in low efficiency of engaged production resources and high dependence on market developments and economic policy (Dulčić \& Petrić, 2001: 37).

Integrated Quality Management (IQM) approach, when it comes to destination, can be defined as a „systematic search for quality in the broader and narrowest sense, i.e. the search for short-term economic improvement and long-term local development. Quality in a narrow sense usually means short-term goals and any improvement in internal quality is currently leading to greater economic effects (total income, profit). Quality in a broader sense or external quality implies development of sustainable tourism..." (Krajnović et al., 2013: $25)$. When it comes to the possibility of applying IQM approaches in the destinations that develop medical tourism, it should be emphasized that medical tourism develops in tourist destinations around the world. Further scientific research in this area would be useful. It should provide an answer as to the standard regulatory model of quality management of tourist destinations, since different tourist destinations in general, as well as those of medical tourism, apply different approaches depending on economic and social system, existing legal regulations, socio-economic environment and the degree of development of receptive country, which, in the case of medical tourism, differ substantially (Ibid.).

\section{Accreditation and international certification of Croatian healthcare institutions}

The accreditation of Croatian healthcare institutions should ensure the establishment and protection of a minimum acceptable quality standard for health services in order to increase the safety and level of customer satisfaction. The responsible institution for the accreditation of healthcare institutions in the Republic of Croatia until the end of 2018 was the Agency for Quality and Accreditation in Health and Social Welfare (http://aaz.hr/o-agenciji). With the entry into force of the Act on Health Care Quality („Official Gazette“ 
118/2018) of January 1, 2019 the Ministry of Health of the Republic of Croatia has taken over all the activities, record office (archive) and other documentation, work resources, rights and obligations and financial resources of the Agency for Quality and Accreditation in Health and Social Welfare (http://www.aaz.hr/hr/vijesti/obavijest-prenosenje-poslova-agencije-za-kvalitetui-akreditaciju-u-zdravstvu-i-socijalnoj).

Competence relates to the field of insurance and improvement of healthcare quality, accreditation in healthcare and health technology assessment processes, as well as in the field of ensuring and enhancing the quality of social services and accreditation of the social welfare holders established by the Act on Health Care Quality („Official Gazette“ 118/2018). Accreditation standards are:

- System of insurance and improvement of health care quality,

- Management of hospital health care facilities (Hospital Health Administration),

- Hospital Health Services Employees,

- Overview of the use of health services,

- Patients' rights,

- Medical documentation service,

- Health care,

- Planning of discharge (Release planning),

- Infection control, and

- Safety management system (http://aaz.hr/hr/akreditacija/standardi).

It should also be emphasized that the planned accreditation system of healthcare institutions in the Republic of Croatia is voluntary and not binding. This accreditation status does not help Republic of Croatia to position itself in the health tourism market.

There is still no autonomous system of certification of health institutions in the Republic of Croatia (National Program - Action Plan for development of health tourism of the Republic of Croatia, 2014: 11). A smaller number of healthcare institutions have basic international certificates, among which the most common ISO standards, and the largest number of health tourism providers in the Republic of Croatia are not certified for the purposes of health-tourism services. International certification of Croatian healthcare institutions should ensure their greater international credibility, and thereby accelerate the acquisition of greater market recognition. Below are listed, and in shorter lines described, some of the healthcare institutions in the Republic of Croatia that have international certificates: Magdalena Clinic from Krapinske Toplice, Special Hospital of St. Catherine in Zabok and Zagreb and Special Hospital Medico in Rijeka.

The Magdalene Clinic from Krapinske Toplice the quality of service and patient safety guarantees with three independent certifications. Certificate ISO 9001 - International Standard, which relates to quality management from internal business organization to the provision of end-users services, the Magdalene Clinic in 2002 is certified by the agency Bureau Veritas Quality International; the Diamond Certificate of the organization Accreditation Canada, a renowned international certification company, which has been certified healthcare institutions in Canada and the world for more than 55 years, certified the Magdalene Clinic in 2017; Certificate ISO EN 15224 - International Standard based on ISO 9001, but related to quality management exclusively for healthcare organizations, the Magdalene Clinic was awarded in 2016 when it was certified as the first hospital to carry this certificate in the Republic of Croatia (http://www.magdalena.hr/).

St. Catherine Special Hospital in Zabok and Zagreb since October 2017 is the carrier of the prestigious Global Healthcare Accreditation, which means that it meets the high clinical standards of excellence and quality in providing health services at the highest international standards. It is the first such accreditation awarded in Europe. Furthermore, St. Catherine Special Hospital is a member of „The Leading Hospitals of the World", which has included a list of the few European health institutions that have been awarded this prestigious certification. This certificate is awarded to hospitals for their excellence in various fields of work primarily for quality of service, the expertise of the staff and others. In June 2015, the International Certification Association (ICERTIAS) St. Catherine Special Hospital declared as the „Best Private Hospital in the Republic of Croatia“. St. Catherine Special Hospital in 2017 became a member of the International Certification Program ICERTIAS „Customers' Friend“ - „Because we value our customers", which confirms the exceptionally high qualitative standards of business and customer and employee relationships. Only institutions that provide a proven relationship with their customers can access the ICERTIAS „Customers' Friend" certification program. St. Catherine Special Hospital in the medicine category achieved the status "Superbrands 2016", and behind the "Superbrands" project, whose home house is in the United Kingdom, is 20 years of successful action in the 88 countries worldwide (https://www.svkatarina.hr/en).

In the Republic of Croatia with certified medical quality operates the Special Hospital Medico in Rije$\mathrm{ka}$, which has been operating to the ISO quality system since 2001, and since 2013 has been the holder of the Temos certificate „Quality in International Patient Care", which determines its position in close markets of Slovenia, Italy and Austria (http://www.medico. hr/o-nama/). 


\section{Potential directions of strategic development of medical tourism in the Republic of Croatia}

Successful tourism development assumes a quality development plan or strategy that is flexible and thorough (Cooper et. al., 2008: 249). As mentioned above, in April 2013 the current Strategy for development of tourism of the Republic of Croatia until 2020 and the Action Plan for the implementation of the Strategy, which contains 26 priority tourism policy measures, were adopted. The function of priority measures is to increase the competitiveness of an integral Croatian tourist product. The measures are focused on the efficiency of the management of a destination tourism product and on the increase of the quality of service and profitability of the business of individual economic entities. The priority measures of tourism policy are divided into two categories: the first category (highest priority) constitute measures without which the initiation and/or implementation is not possible to realize the defined strategic objectives. The second category (medium high priority) consists of measures that are of crucial importance for achieving individual development goals. All the highest priority measures were to be implemented during 2013. One of the priority measures defined in the Strategy for development of tourism of the Republic of Croatia until 2020 is Measure 14: Implementation of the Action Plan for development of health tourism of the Republic of Croatia. The implementation priority of Measure 14 is characterized as medium high. The medium high priority measures were to be implemented for the most part in the period from 2013 to 2015 , or if unexpected circumstances occur, in the period from 2016 to 2020 . (Strategy for development of tourism of the Republic of Croatia until 2020, 2013). As stated above, the defined actions for the implementation of this measure have not been implemented with the planned implementation dynamics defined in the Strategy for development of tourism of the Republic of Croatia until 2020 , which has also influenced the performance results in relation to the set strategic objectives (State Audit Office. Performance Audit Report. Implementation of the measures established by the Strategy for development of tourism of the Republic of Croatia until 2020, 2016).

Furthermore, the interdisciplinary of relationships in health tourism often creates certain difficulties in the development of medical tourism. Therefore, the complexity of the relationship and the mismatch between the relevant legal and regulatory regulations between the Ministry of Health of the Republic of Croatia and the Ministry of Tourism of the Republic of Croatia, directly responsible for this segment, but also the indirectly related Ministry of Culture of the Republic of Croatia and the Ministry of Regional Devel- opment and EU Funds of the Republic of Croatia. The Ministry of Culture of the Republic of Croatia also plays an important role in the development of health tourism, as a large number of spas and special hospitals are located in attractive natural locations that are largely protected as cultural heritage. Regarding fiscal policy measures, cooperation with the Ministry of Finance of the Republic of Croatia is important.

Another disadvantage has become apparent following the entry into force of Directive 2011/24/EU on the application of patients' rights in cross-border healthcare use, adopted on October 25, 2013 (https://eur-lex. europa.eu/LexUriServ/LexUriServ.do?uri=OJ:L:201 1:088:0045:0065:EN:PDF). Without previously regulated domestic legislation, a private healthcare institutions, which is not a contracting institution of the Croatian Health Insurance Fund (HZZO), is placed in an unequal position in the Republic of Croatia. Croatian patients are allowed to use healthcare in certain situations in other European Union member states in public and private healthcare institutions. Patients are entitled to reimbursement for health services at prices defined by Croatian Health Insurance Fund (HZZO). If this same health service can be performed in the Republic of Croatia in a private health institution, patients do not have the right to return funds if that private institution is not a Croatian Health Insurance Fund (HZZO) contractor (most of which are not). This means that Croatian Health Insurance Fund (HZZO) is willing to pay the same service to foreign public and private institutions, and not to domestic private institutions. In this way, patients are stimulated to spend state budget funds outside the Republic of Croatia and create additional travel costs which are not covered by the Croatian Health Insurance Fund (HZZO). Such discrimination in market-oriented healthcare institutions is highly harmful for citizens who prefer treatment in a familiar environment, as well as for healthcare entrepreneurs. All this leads to the outflow of foreign exchange, the departure of the medical staff and the lack of opportunity for the realization of ideas and projects of health or medical tourism. The Strategy for development of tourism of the Republic of Croatia until 2020 states that key concepts which are expected to be more important in shaping health tourism offerings include „innovative“, „authentic“, "green" and "holistic“. In this respect, specific factors of the success of health tourism products relate, above all, to the quality of specialized health centers/institutions, the quality of accompanying tourist offer and the compatible development of the destination.

When we talk about the merger/association, today many countries are faced with the problems of financing and managing public infrastructure. That is why public-private partnerships are an ideal form of merg- 
ing the public and private sector to meet certain public needs. The need for market restructuring occurs due to the fact that the state is not always efficient in the full organization of certain public institutions and that it needs cooperation with the private sector to meet certain objectives/goals (Nikolic \& Maikisch, 2006: 41).

The public sector comprises organizations and institutions financed from the state budget and guided by state services. The private sector encompasses organizations, individuals, companies that are not run by state/government bodies. Public authority determines the objectives/goals of the partnership and raises emphasis on the public interest and quality of services, while the private sector takes care of their interests. The private sector focuses on innovation (introduction of new technology), professional management, efficiency, sustainability of the project life cycle, while the public partner ensures public interest, competitive procurement, supervision of experts and strategic planning. Project analysis determines which model delivers the highest value for money and longterm savings for the public sector. Therefore, publicprivate partnerships projects are never entered if an analysis was not determined to deliver a higher/greater value than the traditional model. Successful tourism development assumes a quality development plan or strategy that is flexible and thorough (Cooper et. al., 2008: 249). Most important, importantly adopted strategies and action plans are implemented in accordance with the basic principles of effective strategic management development.

On issues such as today's health tourism in the Republic of Croatia and how to achieve the set strategic goals, they also sought to respond at the conference "Health Spot Croatia - Croatia, A place for health", held on February 5, 2019 in Zagreb. Approximately 200 local/domestic and foreign participants, representatives of private polyclinics and tourism companies, discussed the perspectives of further development, presented ways of creating new products and experiences, introduced Conference participants with examples of practices and ways of connecting providers of tourism and health services. The Conference emphasized that the Republic of Croatia could increase twice the amount of health tourism that it has achieved today. It also emphasized the important role of the state and the need for synergy between the public and private sectors, without which there is no development of this offer. The Conference emphasized that the offer of health tourism can strongly contribute to the development of all-year tourism and increase investment. In the forthcoming period in the Republic of Croatia, in this type of offer is planned to be invested in: the Special Hospital Varaždin Thermal Bath/Spa and in Bizovac, Krapina and Daruvar Thermal Baths. It is underlined that the legal frameworks for development of health tourism offerings is now regulated, with changes to tourist and health laws, and are in preparation for compliance with the accompanying regulations of law. The Conference emphasized the need for privatization of healthcare, as privatization could result in additional investments and better quality for domestic and foreign patients, and with this approach, a greater number of doctors would remain in the Republic of Croatia. It is important to maintain quality and to be price competitive. The issue of public property ownership is important to resolve to be interesting to investors, and it is important to align standards with European institutions and obtain international certificates, which are some of the key factors for cooperation with international insurance companies that could contribute to increasing the number of foreign patients in Croatian health tourism (https://vlada.gov.hr/vijesti/konferencija-health-spot-croatia-zdravstveni-turizam-donosi500-milijuna-eura-godisnje/25258).

\section{Conclusion}

One of the main characteristics of Croatian tourism is a short season that effectively lasts only a few months a year. Comparative advantages such as the beneficial climate, ecological preservation and richness of cultural and natural heritage represent opportunities for positioning the Republic of Croatia as a year-round tourist destination. But they're not used right now. In order to extend the season, it is necessary to insist on high standards of service quality, training of skilled and educated staff, investments in quality equipment and accommodation units, expansion of additional services, changes to existing laws and legal acts, reduction of adminis- tration, measures of fiscal policy in order to attract investment, more efficient use of European Union funds and more. Therefore, "the sun and the sea" are not sufficient to develop tourism in its entirety, but its development requires effective strategic management of the different types and subtypes of tourism. With the changing trends in tourism and the growing awareness of the importance of preserving health and improving quality of life, health tourism in the world becomes one of the main motives of travel. Health tourism, as one of the specific forms of tourism, demonstrates the strong potential for long-term sustainable development. 
With the Strategy for development of tourism of the Republic of Croatia until 2020 a solid foundation/ basis for development of strategies for other, specific forms of tourism has been created, and the Action Plan for development of health tourism in the Republic of Croatia has been funded and developed, which represents a common, inter-ministerial platform for the systematic increasing of the competitiveness of the health tourism offer. The aforementioned document proposed 30 development activities and programs and defined specific objectives and priorities. Special emphasis has been placed on cooperation between private and public sectors through various forms of public-private partnerships. Such a form of cooperation between public and private sector affects the increase in recognition and competitiveness.

The Action Plan for development of health tourism of the Republic of Croatia contains key analyses of the position of the Republic of Croatia in the market of tourism products, programs and measures, which would lead the Republic of Croatia to the desired position, and detailed analysis of strengths and weaknesses, i.e. opportunities and threats. To achieve the set results, it was necessary to implement the adopted measures, which maximally exploit the strengths and opportunities of health tourism in the Republic of Croatia, i.e. minimizing the impact of its weaknesses and environmental threats. Activities defined in the Action Plan for the implementation of the Strategy for development of tourism of the Republic of Croatia until 2020 aimed at the development of health tourism are part of a medium intensity measure and should have been largely implemented in the first two years after the adoption of a strategic document for the development of Croatian tourism. However, according to the available data, most of the planned activities, these 2019, six years after the adoption of the strategic documents, has not been implemented. It also directly affects the results of the (no)effectiveness of the implementation of the tourism policy measures defined by the Strategy for development of tourism of the Republic of Croatia until 2020, in relation to the set strategic objectives. As one of the indicators is the fact that the current income from health tourism in the Republic of Croatia is approximately 300,000 euros annually, and it is estimated that medical tourism in the Republic of Croatia has the annual potential for much larger income. Also, the share of total tourist income, the measures and activities defined in the Action Plan for development of health tourism of the Republic of Croatia, should have increased from $2 \%$ in 2013 to $15 \%$ in 2020. Given the results of the research, it is unrealistic to expect that the aforementioned strategic objective will actually be achieved. It is apparent from the research that for the development of medical tourism, it is not enough to simply define the key parameters of development in strategic documents, but it is equally important that the measures and activities in the adopted strategic documents are implemented in accordance with the prescribed principles of effective strategic development management within the planned implementation dynamics.

Croatian medicine and dentistry for patients from European countries can offer top quality service and quality, but it is currently not recognized in the right way. The state administration has the opportunity to correct it by implementing priority tourism policy measures, adopted in strategic development documents, whether the Republic of Croatia wants to position itself as a country of reliable quality and reasonable price, not only as a low cost medical tourism destination.

In the Republic of Croatia the prices of medical services are still lower than in the countries of Western Europe, which represents a strong motive for the arrival of "medical tourists“. This provides an ideal opportunity to design an integrated product package that consists of medical, tourist and hospitality services. The Republic of Croatia in order to be positioned in the future as a destination of medical tourism with a distinctive and quality offer, it is necessary to dedicate itself to the integration of the offer, to work on raising the quality of services, specialized sales and promotions. For a more efficient development of medical tourism in the Republic of Croatia, it is necessary to establish a stronger inter-ministerial cooperation in order to establish institutional support for the harmonization and improvement of the legal framework in the function of strengthening entrepreneurship and investment for the development of this form of tourism product. Medical tourism also opens up numerous issues for answers that require multidisciplinary research and open discussions at a scientific and professional level, including all social groups. 


\section{References}

Agencija za kvalitetu i akreditaciju u zdravstvu i socijalnoj skrbi. Početna. Akreditacija. Akreditacijski standardi. (Agency for Quality and Accreditation in Health and Social Welfare. Homepage. Accreditation. Accreditation Standards) http://aaz.hr/hr/ akreditacija/standardi (10.04.2019).

Agencija za kvalitetu i akreditaciju u zdravstvu i socijalnoj skrbi. Početna. O agenciji. (Agency for Quality and Accreditation in Health and Social Welfare. Homepage. About the Agency) http://aaz.hr/oagenciji (10.04.2019).

Agencija za kvalitetu i akreditaciju u zdravstvu i socijalnoj skrbi. Početna. Vijesti. (Agency for Quality and Accreditation in Health and Social Welfare. Homepage. News) http://www.aaz.hr/hr/ vijesti/obavijest-prenosenje-poslova-agencije-zakvalitetu-i-akreditaciju-u-zdravstvu-i-socijalnoj (10.04.2019).

Akcijski plan razvoja golf ponude. (2017). Zagreb: Ministarstvo turizma Republike Hrvatske. (Action plan for development of golf offer. (2017). Zagreb: Ministry of Tourism Republic of Croatia) https:// mint.gov.hr/UserDocsImages/AA 2018 c-dokumenti/180125 akcijski golf.pdf (04.09.2019).

Alfier, D. (1994). Turizam: izbor radova. Zagreb: Institut za turizam. (Tourism: Selection of Works. Zagreb: Institute for Tourism).

Cooper, C., Fletcher, J., Fyall, A., Gilbert, D., \& Wanhill, S. (2008). Ekonomija turizma - Načela i praksa. Split: Ekokon. (Economy of Tourism - Principles and Practice. Split: Ekokon).

Čavlek, N., Bartoluci, M., Prebežac, D., \& Kesar, O. (2011). Turizam - ekonomske osnove i organizacijski sustav. Zagreb: Školska knjiga. (Tourism - the economic base and organizational system. Zagreb: Školska knjiga).

Directive 2011/24/EU https://eur-lex.europa.eu/LexUriServ/LexUriServ.do?uri=OJ:L:2011:088:0045:00 65:EN:PDF (18.04.2019).

Dulčić, A., \& Petrić, L. (2001). Upravljanje razvojem turizma. Zagreb: Mate. (Managing the development of tourism. Zagreb: Mate).

Državni ured za reviziju. Izvješće o obavljenoj reviziji učinkovitosti. Provedba mjera utvrđenih Strategijom razvoja turizma Republike Hrvatske do 2020. (State Audit Office. Performance Audit Report. Implementation of the measures established by the Strategy for development of tourism of the Republic of Croatia until 2020). (2016). Zagreb.

Geić, S. (2011). Menadžment selektivnih oblika turizma. Split: Sveučilište u Splitu. (Management of the selective forms of tourism. Split: University of Split).
Goldbach, A. R., \& West, D. J. (2010). Medical Tourism: a New Venue of Healthcare. Journal of Global Business Issues, 4(2), 43-53.

Gržinić, J., \& Bevanda, V. (2014). Suvremeni trendovi u turizmu. Pula: Fakultet ekonomije i turizma „Dr. Mijo Mirković". (Contemporary trends in tourism. Pula: Faculty of Economics and Tourism „Dr. Mijo Mirković").

Hrturizam.hr. Turistički News Portal. Opatija domaćin IMTJ Medical Travel Summita 2017. (Hrturizam.hr. Tourist News Portal. Opatija hosts IMTJ Medical Travel Summit 2017) http://hrturizam.hr/opatija-domacin-imtj-medical-travel-summita-2017/ (10.04.2019).

HSO - Health Standards Organization http://healthstandards.org/ (10.04.2019).

IMTJ. International Medical Travel Journal. The World Leading Journal for the Medical Travel Sector. Home https://www.imtj.com/ (10.04.2019).

IMTJ. International Medical Travel Journal. The World Leading Journal for the Medical Travel Sector. What We Do_https://www.imtj.com/what-wedo/ (10.04.2019).

Jadrešić, V. (2001). Turizam u interdisciplinarnoj teoriji i primjeni - zbornik istraživanja. Zagreb: Školska knjiga. (Tourism in interdisciplinary theory and use - Research Proceedings. Zagreb: Školska knjiga).

Klinika Magdalena. (The Magdalene Clinic) http:// www.magdalena.hr/ (10.04.2019).

Krajnović, A., Babić, R., \& Bosna, J. (2013). Medicinski turizam - neki marketinški i etički aspekti. (Medical Tourism - Some Marketing and Ethical Aspects). Oeconomica Jadertina, 3(1), 16-30.

Madžar, T., Lazibat, T., \& Mikulić, J. (2016). Mjerenje kvalitete usluga u zdravstvenom turizmu. Poslovna izvrsnost. (Measuring Quality of Services in Health Tourism. Business Excellence), 10(1), 187-202.

Medical Tourism Association http://www.medicaltourismassociation.com (10.04.2019).

Medico Specijalna bolnica. Početna. O Specijalnoj bolnici Medico. (Medico Special Hospital. Home. About the Special Hospital Medico) http://www. medico.hr/o-nama/ (10.04.2019).

Milas, Lj. (2015). Potencijali za razvoj zdravstvenog turizma. Zagreb: Hrvatska gospodarska komora, Sektor za turizam. (Potentials for development of health tourism. Zagreb: Croatian Chamber of Economy, Sector for Tourism).

Ministarstvo turizma Republike Hrvatske. Naslovnica. Istaknute teme. Strategija razvoja turizma. Akcijski planovi. (Ministry of Tourism Republic of Croatia. Home page. Featured topics. Strategy for 
development of tourism. Action Plans https://mint. gov.hr/istaknute-teme/strategija-razvoja-turizma-11411/akcijski-planovi-15525/15525 (04.09.2019).

Nacionalni program - Akcijski plan razvoja kongresnog turizma. (2013/2016). Zagreb: Ministarstvo turizma Republike Hrvatske, Institut za turizam. (National program - Action Plan for development of congress tourism. (2013/2016). Zagreb: Ministry of Tourism Republic of Croatia, Institute for Tourism https://mint.gov.hr/UserDocsImages/AA 2018 c-dokumenti/akcijski\%2oplanovi/o01 170120 akc p kongres.pdf (04.09.2019).

Nacionalni program - Akcijski plan razvoja zdravstvenog turizma. (2014). Zagreb: Ministarstvo turizma Republike Hrvatske, Institut za turizam. (National program - Action Plan for development of health tourism of the Republic of Croatia. (2014). Zagreb: Ministry of Tourism Republic of Croatia, Institute for Tourism) https://mint.gov.hr/UserDocsImages//arhiva//150608 AP \%20Zdravstveni\%2oturizam.pdf (10.04.2019).

Nacionalna strategija razvoja zdravstva Republike Hrvatske 2012.-2020. (2012). Zagreb: Vlada Republike Hrvatske, Ministarstvo zdravlja Republike Hrvatske. (National strategy for development of healthcare of the Republic of Croatia 2012-2020. (2012). Zagreb: Government of the Republic of Croatia, Ministry of Health of the Republic of Croatia)__https://zdravlje.gov.hr/UserDocsImages/dokumenti/Programi,\%20projekti\%20i\%2ostrategije/ Skracena\%2oNacionalna\%2ostrategija\%2orazvoja\%2ozdravstva\%20-\%20HRV\%20-\%20za\%2oweb. pdf (10.04.2019).

Nacionalno vijeće za konkurentost. Hrvatska među najkonkurentnijim zemljama svijeta. (National Competitiveness Council. Croatia is among the most competitive countries in the world) http:// konkurentnost.hr/hrvatska-medu-turisticki-najkonkurentnijim-zemljama-svijeta/ (04.09.2019).

Nikolic, I. A., \& Maikisch, H. (2006). Public-Private Partnerships and Collaboration in the Health Sector. An Overwiew with Case Studies from Recent European Experiences. The World Bank http://citeseerx.ist.psu.edu/viewdoc/download?doi=10.1.1.490 $3442 \&$ rep $=$ rep1\&type $=$ pdf $(10.04 .2019)$.

St. Catherine. European Center of Excellence https:// www.svkatarina.hr/en (10.04.2019).
Strategija razvoja turizma Republike Hrvatske do 2020. godine. (2013). Zagreb: Ministarstvo turizma Republike Hrvatske. (Strategy for development of tourism of the Republic of Croatia until 2020. (2013). Zagreb: Ministry of Tourism Republic of Croatia) https://narodne-novine.nn.hr/clanci/sluzbeni/2013 $05 \quad 55$ 1119.html (10.04.2019).

The Travel \& Tourism Competitiveness Report 2017. Paving the way for a more sustainable and inclusive future. (2017). Geneva: World Economic Forum http://konkurentnost.hr/wp-content/uploads/2018/01/WEF TTCR 2017 web 0401-1-1.pdf (04.09.2019).

Turner, L. (2007). 'First World Healthcare at Third World Prices': Globalization, Bioethics and Medical Tourism. BioSocieties, 2, 303-325. DOI 10.1017/ S1745855207005765

Usluga vrednovanje u tijeku provedbe Strategije razvoja turizma Republike Hrvatske do 2020. godine (interim evaluacija). (2017). Zagreb: Institut za razvoj i međunarodne odnose. (Evaluation in the course of implementation of the Strategy for development of tourism of the Republic of Croatia until 2020 (interim evaluation). (2017). Zagreb: Institute for Development and International Relations).

Vlada Republike Hrvatske. Naslovnica Vlade RH. Vijesti. (2019). Konferencija „Health Spot Croatia": Zdravstveni turizam donosi 500 milijuna eura godišnje. (Government of the Republic of Croatia. Home. News. (2019). Health Spot Croatia Conference: Health tourism brings 500 million euros annually) https://vlada.gov.hr/vijesti/konferencija-health-spot-croatia-zdravstveni-turizam-donosi-500-milijuna-eura-godisnje/25258 (10.04.2019).

Youngman, I. (2016) Medical Tourism in 2016: What Has Changed? https://www.imtj.com/articles/medical-tourism-2016-what-has-changed/ (10.04.2019).

Zakon o kvaliteti zdravstvene zaštite, „Narodne novine“ 118/2018. (Act on Health Care Quality, „Official Ga-

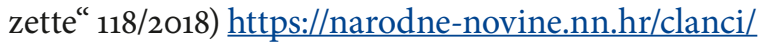
sluzbeni/2018 $12 \quad 118 \quad 2339 . h t m l$ (10.04.2019).

Zaninović, V. (2003). Segmentacija i poticanje selektivnih oblika turizma - spoj izvornoga i modernoga. (Segmentation and encouragement of selective forms of tourism - a combination of original and modern). Tourism and Hospitality Management, 9(2), 271-288. 